\title{
A Review on the Cadmium Content of Rice, Daily Cadmium Intake, and Accumulation in the Kidneys
}

\author{
Tomoyuki KawAdA and Shosuke SuzUKI \\ Department of Public Health, Gunma University School of Medicine, Maebashi, Japan
}

\begin{abstract}
A Review on the Cadmium Content of Rice, Daily Cadmium Intake, and Accumulation in the Kidneys: Tomoyuki KaWADA, et al. Department of Public Health, Gunma University School of Medicine-The body burden of cadmium primarily depends on the daily intake of the element in food, and thus the geographical differences in cadmium content in foods and the daily intake of cadmium should be studied. There is a food chain from soil through plant and animal foods to man. Estimation of daily cadmium intake according to the geographical region is important for monitoring environmental cadmium pollution and health effects. In the 1990s, the daily intake of cadmium and accumulation in the kidney were reported. Japanese have a relatively high daily intake of cadmium, although the percentage daily cadmium intake obtained from rice decreased from $50 \%$ in 1970 to $34 \%$ in 1994 . This change is proportional to the change in average rice consumption from $261 \mathrm{~g} /$ day in 1970 to $182 \mathrm{~g} /$ day in 1994 . These changes also indicate a reduced cadmium burden in the past twenty years, from 35-50 $\mu \mathrm{g} /$ day to $30 \mu \mathrm{g} /$ day. The cadmium level in the renal cortex of Japanese is the highest in the world, but the cadmium in the kidney has been decreasing in most Japanese.
\end{abstract}

(J Occup Health 1998; 40: 264-269)

Key words: Cadmium in rice, Daily intake of cadmium, Cadmium accumulation in the kidneys, General inhabitants

In mammals cadmium is known to accumulate exclusively in the kidneys, and it has a long biological half-life in the human body, ranging from 10 to 33 years ${ }^{1.2)}$. The amount of cadmium that has accumulated in the kidneys is a function of age and/or daily cadmium intake, and the latter is mainly from food, beverages and smoking ${ }^{2-5)}$. Cadmium in drinking water and in the atmosphere contributes little

Received May 22, 1998; Accepted July 7, 1998

Correspondence to: T. Kawada, Department of Public Health,

Gunma University School of Medicine, Showa, Maebashi 371-8511, Japan to the daily intake of cadmium ${ }^{6}$.

Man is an element in an ecosystem. The cadmium pathways to man are soil-plant-animal-man and soil-plantman. Cadmium-rich soil generally results in cadmiumrich food, and geographical differences have been reported in daily cadmium intake and cadmium accumulation in the kidneys ${ }^{2,4,7,8)}$.

Earlier investigators reported finding that Japanese have the highest renal cadmium levels in the world, followed by rice-eating ethnic groups such as the people of Thailand, Hong Kong and Taiwan, with the lowest levels in people in the United States, Switzerland, India, Nigeria, and Rwanda-Burundi ${ }^{2,9 j}$. Data for cadmium concentrations in the human renal cortex range from an average of 10 to $30 \mu \mathrm{g} / \mathrm{g}$ wet weight for Europeans, Americans and Africans, but from 65 to $115 \mu \mathrm{g} / \mathrm{g}$ wet weight for Japanese (Table 1) ${ }^{10-16)}$. Renal cadmium content is governed by cadmium absorbed from the digestive tract and respiratory organs that comes from food, beverages and cigarettes, which originate in the soil. The cadmium content of plants varies from place to place on the earth. Baseline studies on environmental monitoring of cadmium is needed, but the data are very limited ${ }^{2,3)}$.

Suzuki and Lu previously estimated the daily cadmium intake in Japan, the United States and Indonesia by food and feces analysis. The daily cadmium intake of two men in Tokyo averaged 48.2 and $46.9 \mu \mathrm{g} / \mathrm{day} /$ person based on a 30-day another meal method, versus 35.9 and 36.0 based on a 30 -day feces analysis ${ }^{17}$. The daily cadmium intake in Houston, Texas, ranged from 11.9 to 18.2 based on food analysis and a market-basket surve ${ }^{18)}$. The daily cadmium intake on Java Island, Indonesia, was estimated to be 17.2 based on food analysis of a 5 -day menu ${ }^{19}$.

The authors have reviewed recent data on cadmium accumulation and daily intake to assess geographical differences, in addition the data obtained in our own surveys in Japan, the United States and Indonesia from 1972 to 1985 . The samples were mainly measured by atomic absorption spectrophotometry (flame or flameless). The target subjects were male and female 
Table 1. Geographical difference in cadmium concentration in the kidney cortex in several countries in the 1960s, 1970s and 1980s

\begin{tabular}{|c|c|c|c|c|c|c|}
\hline Country & Ref. & Age & $\operatorname{sex}$ & Mean & (SD) & Analytical method \\
\hline USA & 9 & & & 29.1 & & Freeze-dry,emission $\mathrm{S}$ \\
\hline Switzerland & 10 & & & 31.1 & & Dry, emission $\mathrm{S}$ \\
\hline Rwanda- & 10 & & & 9.8 & & Dry ash, emission S \\
\hline \multicolumn{7}{|l|}{ Burundi } \\
\hline Nigeria & 10 & & & 23.3 & & Dry ash, emission $\mathrm{S}$ \\
\hline Indonesia & - & $46-59$ & $\mathrm{M} \& \mathrm{~F}$ & 19.5 & $(0.33)^{\mathrm{G}}$ & Wet ash, Flameless AAS \\
\hline Sweden & 15 & $40-49$ & Male & 19.3 & $(1.80)^{\mathrm{G}}$ & Dry ash, Flame AAS \\
\hline Sweden & 15 & $40-49$ & Female & 25.8 & $(1.65)^{\mathrm{G}}$ & Dry ash, Flame AAS \\
\hline Sweden & 15 & $50-59$ & Male & 15.6 & $(2.48)^{\mathrm{G}}$ & Dry ash, Flame AAS \\
\hline Sweden & 15 & $50-59$ & Female & 21.2 & $(2.05)^{\mathrm{G}}$ & Dry ash, Flame AAS \\
\hline West Germany & 11 & $41-50$ & Male & $23.2^{\mathrm{G}}$ & & Wet ash,Flameless AAS \\
\hline West Germany & 11 & $51-60$ & Male & 17.5 & $(1.3)^{\mathrm{G}}$ & Wet ash, Flameless AAS \\
\hline West Germany & 11 & $41-50$ & Female & 16.8 & $(1.3)^{G}$ & Wet ash, Flameless AAS \\
\hline West Germany & 11 & $51-60$ & Female & 12.7 & $(2.1)^{\mathrm{G}}$ & Wet ash, Flameless AAS \\
\hline Japan & 12 & $40-59$ & Male & 87 & (37) & Flame AAS \\
\hline Japan & 12 & $40-59$ & Female & 99 & (20) & Flame AAS \\
\hline Japan & 13 & 39 (Mean) & & 58.8 & & Wet ash, Flame AAS \\
\hline Japan & 14 & $40-49$ & & 85.1 & $(47.49)$ & Wet ash, Flame AAS \\
\hline Japan & 14 & $50-59$ & & 125.3 & (56.74) & Wet ash, Flame AAS \\
\hline Japan & 15 & $40-49$ & Male & 43.2 & $(1.65)^{\mathrm{G}}$ & Wet ash, Flame AAS \\
\hline Japan & 15 & $40-49$ & Female & 82.7 & $(1.51)^{\mathrm{G}}$ & Wet ash, Flame AAS \\
\hline Japan & 15 & $50-59$ & Male & 65.0 & $(2.17)^{\mathrm{G}}$ & Wet ash, Flame AAS \\
\hline Japan & 15 & $50-59$ & Female & 63.2 & $(1.42)^{\mathrm{G}}$ & Wet ash, Flame AAS \\
\hline Japan & 16 & $40-49$ & Male & 114.1 & $(37.2)$ & Wet ash, Flame AAS \\
\hline
\end{tabular}

G; Geometric mean and/or geometric standard deviation, S; spectrophotometer

AAS; atomic absorption spectrophotometer

inhabitants in non-cadmium-polluted areas and their average age was 50 years.

The purpose of this review was to identify trends in cadmium exposure in ordinally inhabitants, especially net cadmium intake by ingestion. This will be useful as baseline data for cadmium intake except via smoking or occupational exposure.

\section{Geographical differences in the cadmium content in rice}

Many surveys have reported finding showing that rice produced in Japan contained the highest cadmium levels among samples collected from several different areas in the world ${ }^{20,21)}$. A survey on the cadmium content of rice in samples from 22 countries by Masironi et al. ${ }^{21)}$ revealed the lowest level, $2 \mathbf{n g} / \mathrm{g}$, in rice from Brazil and the highest level, $65 \mathrm{ng} / \mathrm{g}$, in rice from Japan. The Japanese Government's program to replace polluted rice field soil is being carried out. Suzuki et al. reported an arithmetic mean and SD in Indonesian rice of $40 \pm 42 \mathrm{ng} / \mathrm{g}$ and a geometric mean of $31 \mathrm{ng} / \mathrm{g}^{22)}$. The mean and SD for cadmium in rice from Spain was $32.2 \pm 25.94 \mathrm{ng} / \mathrm{g}^{23)}$. In
China, the average value for cadmium in polished rice from a non-polluted area was $60 \mathrm{ng} / \mathrm{g}^{24)}$. These results show that considerable geographical differences exist in the cadmium content of rice.

The rice of West Java has been found to have double the cadmium content of rice from Central and East Java ${ }^{22}$. The soil type in West Java is Ultisol, as opposed to Vertisol in East Java. The soil type in Western Japan is also Ultisol, and this may explain the higher cadmium levels ${ }^{25}$.

The cadmium content of soil also differs very much from place to place, and this may be responsible for the difference in the amount of rice in plant foods produced in soil. The correlation between cadmium content in soil and rice is low within the same area but high between different areas $^{26)}$.

\section{Daily cadmium intake}

There are four ways of estimating of daily cadmium intake. The first is another meal method or duplicate portions method. The total diet is usually mixed or homogenized, and part of it is taken for analysis. The second method is the market-basket method for 
Table 2. Geographical difference in daily intake of cadmium by duplicate meal method published in the $1990 \mathrm{~s}$

\begin{tabular}{lccll}
\hline Country & Ref. & \multicolumn{2}{c}{ Mean (SD) } & Analytical method \\
\hline Spain & 23 & 18.18 & Wet ash, Flameless AAS \\
Germany & 29 & $9.7(8.1)$ & Dry ash, Flame AAS \\
Sweden & 30 & $11.1(4.2)$ & Dry ash, Flame AAS \\
Sweden & 31 & 12 & & Flameless AAS \\
China & 32 & $9.9(2.33)^{\mathrm{G}}$ & Wet ash, Flameless AAS \\
Taiwan & 33 & $10.1(1.70)^{\mathrm{G}}$ & Wet ash, Flameless AAS \\
Croatia & 34 & 17.34 & Dry ash, Flame AAS \\
Finland & 35 & $14.5(3.1)$ & Flameless AAS \\
Korea & 36 & $21.2^{\mathrm{G}}$ & Wet ash, Flameless AAS \\
Japan & 32 & $32.1 \quad(1.93)^{\mathrm{G}}$ & Wet ash, Flameless AAS \\
Japan & 37 & $30.0(2.09)^{\mathrm{G}}$ & Wet ash, Flameless AAS \\
\hline
\end{tabular}

$\mathrm{G}$; Geometric mean and/or geometric standard deviation

AAS; atomic absorption spectrophotometer

Table 3. Geographical difference in cadmium concentration in the kidney cortex published in the $1990 \mathrm{~s}$

\begin{tabular}{lccll}
\hline Country & Ref. & Smoke & Mean (SD) & \multicolumn{1}{c}{ Analytical method } \\
\hline Poland & 4 & - & $28.5(1.9)^{\mathrm{G}}$ & Wet ash, Flame AAS \\
Spain & 39 & $+\&-$ & $14.6(5.9)$ & Wet ash, Flameless AAS \\
Poland & 40 & - & $16.5(1.8)^{\mathrm{G}}$ & Wet ash, Flame AAS \\
Poland & 41 & - & $26.3(23.5)$ & Wet ash, Flame AAS \\
Germany & 42 & $+\&-$ & $55.2(50)$ & ICP \\
Sweden & 43 & - & 62.8 & Wet ash, Flameless AAS \\
Japan & 44 & $+\&-$ & $52.2^{\mathrm{G}}$ & Wet ash, AAS* \\
\hline
\end{tabular}

G; Geometric mean and/or geometric standard deviation

*; Flame or flameless atomic absorption spectrophotometer

Some dissociation existed in daily intake of cadmium and its accumulation in the kidneys for example in Germany and Sweden.

individuals and total diet method for populations. Foods and beverages are sampled and bought in representative retail shops in the area and analyzed for the element. The cadmium content of the same food item is averaged and multiplied by individual food consumption data or by the national food balance sheet data. The third method is estimation of daily cadmium intake from daily cadmium excretion in feces. Daily cadmium in feces equals about $95 \%$ of the daily oral cadmium intake ${ }^{27}$. Approximate daily cadmium intake is roughly calculated from the feces data multiplied by a factor of $100 / 95^{28}$. The last method is estimation by using a nomogram indicating the relation between the average concentration of cadmium in the kidneys at age 50 and the average daily cadmium intake in an area or a country.

Daily cadmium intake is reported to be low in Germany ${ }^{29)}$, Sweden ${ }^{30,31)}$, China ${ }^{32)}$ and Taiwan ${ }^{33 \text {. }}$. The intake values in Croatia ${ }^{34)}$, Finland ${ }^{351}$ and Spain ${ }^{23)}$ are moderate. Most mean values range from 10 to $20 \mu \mathrm{g} /$ day. Data reported from Korea ${ }^{36)}$ and Japan ${ }^{32,37)}$ are high, ranging from 20 to $30 \mu \mathrm{g} / \mathrm{day} /$ person (Table 2). This is consistent with the moderate accumulation of the element in the renal cortex of Japanese $e^{2,38)}$.

\section{Cadmium in the renal cortex}

The renal cortex is a critical organ in terms of longterm exposure to cadmium. Cadmium content data for the renal cortex reported recently have shown the lowest values in Spain ${ }^{39)}$ and Poland ${ }^{4.40,41)}$ and relatively high values, exceeding $50 \mu \mathrm{g} / \mathrm{g}$, in Germany ${ }^{42)}$ and Sweden ${ }^{43)}$. In Japan, Koizumi et al. reported 130 and $21 \mu \mathrm{g} / \mathrm{g}$ as GM $x \div$ GSD, respectively, from which a geometric mean of $52.2 \mu \mathrm{g} / \mathrm{g}$ was calculated ${ }^{44)}$ (Table 3 ). The WHO recommendation ${ }^{45)}$ states that the critical concentration 
of cadmium in the renal cortex is about $200 \mu \mathrm{g} / \mathrm{g}$. The standard deviation of the data for Germany is 50 , so that the values in under $1 \%$ of the target population exceed $200 \mu \mathrm{g} / \mathrm{g}$.

\section{Comments}

The daily cadmium intake and renal cortex cadmium concentration data over the past quarter of a century are plotted in Fig. 1. Rice eaters have been said to ingest about a half or more of their daily cadmium intake from rice $^{45)}$. The latest data in Japan show that one third of the daily cadmium intake comes from rice. Compared with the data for Japan in the $1970 \mathrm{~s}^{17,38,46)}$, which ranged from 35 to $50 \mu \mathrm{g} / \mathrm{day}$, the daily intake of cadmium has decreased recently. This may be partly attributable to decreased rice consumption, which averaged $261 \mathrm{~g} /$ day

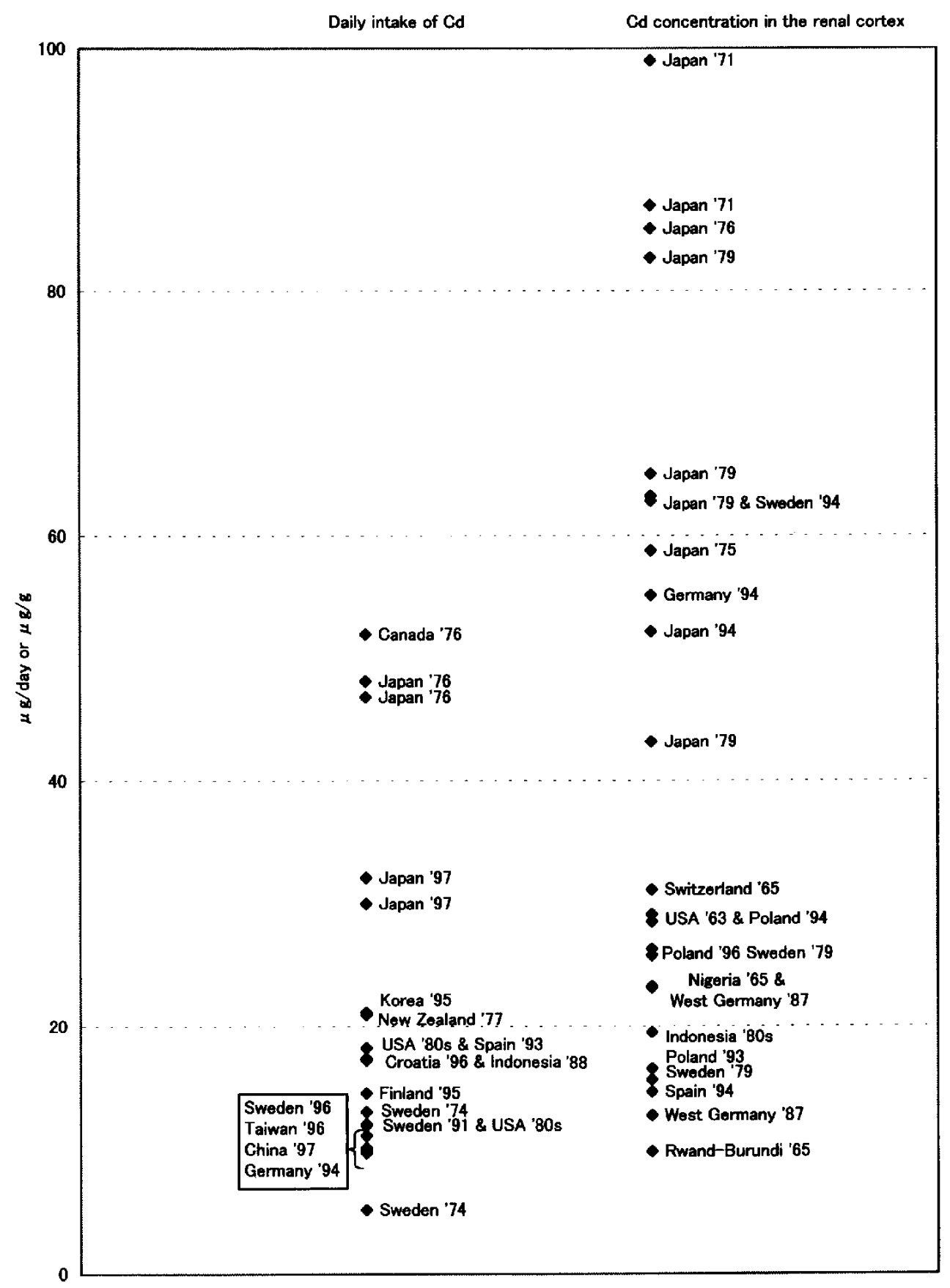

Fig. 1. Daily intake of cadmium and its concentration in the renal cortex. Over $100 \mu \mathrm{g} / \mathrm{g}$ of cadmium in the renal cortex was also reported in the 1970s and 1980s in Japan. 
in 1970 and $182 \mathrm{~g}$ /day in $1994^{47)}$, in addition to the elimination of polluted rice from the market and increased consumption of imported foods.

The criteria for food being a good indicator of cadmium intake are: large and widespread consumption, ubiquitous cultivation throughout the world, and easy sampling, transportation, and conservation ${ }^{2)}$. Rice, wheat, and a few vegetables, such as carrots, are therefore the best indicator foods for cadmium. Although the consumption of rice has been decreasing, e.g., in Japan, daily cadmium intake can be roughly estimated by analysis of the cadmium content in the rice people eat. Rice is the best indicator food for cadmium monitoring in rice-eating ethnic groups. Sources of daily cadmium intake in nonrice-eaters are cereals, vegetables and potatoes, although non-rice-eaters are usually not in the high-risk group for cadmium intake.

\section{References}

1) Ellis KJ, Vartsky D, Zanzi I, Cohn SH, Yasumura S. Cadmium: in vivo measurement in smokers and nonsmokers. Science 1979; 205: 323-325.

2) Suzuki S, Koyama H, Hattori T, Kawada T, Rivai IF. Daily intake of cadmium: an ecological view. Proceedings of Asia-Pacific Symposium on Environmental and Occupational Toxicology, 1988: 205-217.

3) Friberg L, Vahter M. Assessment of exposure to lead and cadmium through biological monitoring: results of a UNEP/WHO global study. Environ Res 1983; 30: 95-128.

4) Bem EM, Orlowski C, Piotrowski JK, Januszewski K, Pajak J. Cadmium, zinc, copper, and metallothionein levels in the kidney and liver of inhabitants of upper Silesia (Poland). Int Arch Occup Environ Health 1993; 65: 57-63.

5) Nilsson U, Schütz A, Skerfving S, Mattsson S. Cadmium in kidneys in Swedes measured in vivo using $\mathrm{X}$-ray fluorescence analysis. Int Arch Occup Environ Health 1995; 67: 405-411.

6) Nordberg GF, Nordberg M. Biological monitoring of cadmium. In Clarkson TW, Friberg L, Nordberg GF, Sager PR eds. Biological monitoring of toxic metals, Plenum, New York, 1988: 151.

7) Friberg L, Piscator $M$, Nordberg GF, Kjellström T. Cadmium in the environment. $2^{\text {nd }}$ ed. Boca raton FL: CRC Press, 1974.

8) López-Artiguez M, Cameán A, González G, Repetto M. Cadmium concentrations in human renal cortex tissue (necropsies). Bull Environ Contam Toxicol 1995; 54: 841-847.

9) Perry HM, Tipton IH, Schroeder HA, Steiner RL, Cook MJ. Variation in the concentration of cadmium in human kidney as a function of age and geographic origin. J Chronic Dis 1961; 14: 259-271.

10) Cherry WC. Distribution of cadmium in human tissues. In: Nriagu JO, ed. In Cadmium in the environment, Part 2. Health effect. New York: John Willey \& Suns,
1981: 69 .

11) Hahn R, Ewers U, Jermann E, Freier I, Brockhaus A, Schlipköter HW. Cadmium in kidney cortex of inhabitants of North-West Germany: its relationship to age, sex, smoking and environmental pollution by cadmium. Int Arch Occup Environ Health 1987; 59: $165-176$.

12) Ishizaki A, Fukushima M, Sakamoto M. Contents of cadmium and zinc of Itai-itai disease patients and residents of Hokuriku district. Nippon Eiseigaku Zasshi 1971; 26: 268-273 (in Japanese).

13) Sumino K, Hayakawa K, Shibata T, Kitamura S. Heavy metals in normal Japanese tissues. Amounts of 15 heavy metals in 30 subjects. Arch Environ Health 1975; 30: 487-494.

14) Tsuchiya K, Seki $Y$, Sugita M. Cadmium concentrations in the organs and tissues of cadavers from accidental deaths. Keio J Med 1976; 25: 83-90.

15) Kjellström $T$. Exposure and accumulation of cadmium in populations from Japan, the United States, and Sweden. Environ Health Perspectives 1979; 28: 169 197.

16) Kobayashi S. Effect of aging on the concentration of cadmium, zinc and copper in human kidney. Nippon Koshu Eisei Zasshi 1983; 30: 27-34 (in Japanese).

17) Suzuki S. and Lu CC. A balance study of cadmiuman estimation of daily input, output and retained amount in two subjects. Ind Health 1976; 14: 53-65.

18) Suzuki S. unpublished data.

19) Suzuki S, Hyodo K, Koyama H, Djuangsih N, Soemarwoto $\mathrm{O}$. Estimation of daily intake of cadmium from foods and drinks, and from feces at three kampungs of Java Island. In: Suzuki S, ed. Health Ecology in Indonesia. Tokyo: Gyosei, 1988: 65-73.

20) Rivai IF, Koyama H, Suzuki S. Cadmium content in rice and its daily intake in various countries. Bull Environ Contam Toxicol 1990; 44: 910-916.

21) Masironi R, Koirtyohann SR, Pierce JO. Zinc, copper, cadmium and chromium in polished and unpolished rice. Sci Total Environ 1977; 7: 27-43.

22) Suzuki S, Djuangsih N, Hyodo K, Soemarwoto $O$. Cadmium, copper, and zinc in rice produced in Java. Arch Environ Contam Toxicol 1980; 9: 437 449.

23) López-Artiguez M, Soria ML, Cameán A, Repetto $M$. Cadmium in the diet of the local population of Seville (Spain). Bull Environ Contam Toxicol 1993; 50: 417424.

24) Cai S, Yue L, Shang Q, Nordberg G. Cadmium exposure among residents in an area contaminated by irrigation water in China. Bull World Health Organ 1995; 73: 359-367.

25) Rivai IF, Koyama H, Suzuki S. Cadmium content in rice and rice field soil in China, Indonesia, and Japan, with special reference to soil type and daily intake. Minzoku Eisei 1990; 56: 168-177.

26) Suzuki S, Iwao S. Cadmium, copper, and zinc levels in the rice and rice field soil of Houston, Texas. Biol Trace Elem Res 1982; 4: 21-28.

27) Friberg L, Kjellström T, Nordberg GF. Cadmium. In Friberg L, Nordberg GF, Vouk V eds. Handbook on 
the toxicology of metals. $2^{\text {nd }}$ ed. Vol II, Amsterdam: Elsevier, 1986: 140.

28) Kowal NE, Johnson DE, Kraemer DF, Pahren HR. Normal levels of cadmium in diet, urine, blood, and tissues of inhabitants of the United States. J Toxicol Environ Health 1979; 5: 995-1014.

29) Müller M, Anke M. Distribution of cadmium in the food chain (soil-plant-human) of a cadmium exposed area and the health risks of the general population. Sci Total Environ 1994; 156: 151-158.

30) Vahter M, Berglund M, Nermell B, Åkesson A. Bioavailability of cadmium from shellfish and mixed diet in women. Toxicol Appl Pharmacol 1996; 136: 332-341.

31) Becker W, Kumpulainen J. Contents of essential and toxic mineral elements in Swedish market-basket diets in 1987. Br J Nutr 1991; 66: 151-160.

32) Zhang $Z W$, Moon CS, Watanabe T, Shimbo S, He FS, Wu YQ, Zhou SF, Su DM, Qu JB, Ikeda M. Background exposure of urban populations to lead and cadmium: comparison between China and Japan. Int Arch Occup Environ Health 1997; 69: 273-281.

33) Ikeda $M$, Zhang $Z W$, Moon CS, Imai $Y$, Watanabe $T$, Shimbo S, Ma WC, Lee CC, Guo YL. Background exposure of general population to cadmium and lead in Tainan city, Taiwan. Arch Environ Contam Toxicol 1996; 30: 121-126.

34) Sapunar-Postruznik J, Bazulic D, Kubala H, Balint L. Estimation of dietary intake of lead and cadmium in the general population of the Republic of Croatia. Sci Total Environ 1996; 177: 31-35.

35) Louekari K, Valkonen S, Pousi S, Virtanen L. Estimated dietary intake of lead and cadmium and their concentration in blood. Sci Total Environ 1991; 105: $87-99$.

36) Moon CS, Zhang ZW, Shimbo S, Watanabe T, Moon DH, Lee CU, Lee BK, Ahn KD, Lee SE, Ikeda M. Dietary intake of cadmium and lead among the general population in Korea. Environ Res 1995; 71: 46-54.

37) Watanabe $T$, Nakatsuka $H$, Shimbo $S$, Iwami $O$, Imai Y, Moon CS, Zhang ZW, Iguchi H, Ikeda M. Reduced cadmium and lead burden in Japan in the past 10 years. Int Arch Occup Environ Health 1996; 68: 305-314.

38) Tsuchiya K. Cadmium in human urine, feces, blood, hair, organs, and tisues. In Tsuchiya $\mathrm{K}$ ed. Cadmium studies in Japan: a review. Tokyo: Kodansha, 1978: $37-43$.

39) Torra M, To-Figueras J, Brunet $\mathbf{M}$, Rodamilans $\mathbf{M}$, Corbella J. Total and metallothionein-bound cadmium in the liver and the kidney of a population in Barcelona (Spain). Bull Environ Contam Toxicol 1994; 53: 509515.

40) Bem EM, Piotrowski JK, Turzyńska E. Cadmium, zinc, and copper levels in the kidneys and liver of the inhabitants of north-eastern Poland. Pol J Occup Med Environ Health 1993; 6: 133-141.

41) Orlowski C, Piotrowski JK, Kubów M. The levels of cadmium, zinc and copper in the renal cortex and liver of the inhabitants of the copper basin. Int J Occup Med Environ Health 1996; 9: 255-263.

42) Müller I, Helmers E, Barchet R, Schweinsberg F. Cadmium concentration in the renal cortex of kidney tumor patients and controls. J Trace Elem Electrolytes Health Dis 1994; 8: 173-176.

43) Hardell L, Wing AM, Ljungberg B, Dreifaldt AC, Degerman A, Halmans $G$. Levels of cadmium, zinc and copper in renal cell carcinoma and normal kidney. Eur J Cancer Prev 1994; 3: 45-48.

44) Koizumi N, Hatayama F, Sumino K. Problems in the analysis of cadmium in autopsied tissues. Environ Res 1994; 64: 192-198.

45) Friberg L, Kjellström T, Nordberg GF. Cadmium. In: Friberg L, Nordberg GF, Vouk V, eds. Handbook on the toxicology of metals. $2^{\text {nd }}$ ed. Vol II. Amsterdam: Elsevier, 1986: 166-169.

46) Iwao S. Cadmium, lead, copper and zinc in food, feces and organs of humans. Interrelationships in food and feces and interactions in the liver and the renal cortex. Keio J Med 1977; 26: 63-78.

47) Ministry of Agriculture, Forestry and Fisheries. Food Balance Sheet, Minister's Secretariat, 1995. (This table is based upon FAO's preparation guide. Period is one year from April 1 st to March 31st of the following year. Total population used in calculating supplies per capita is 125034 thousand (as of Oct. 1st, 1994) estimated by Statistics Bureau, Management and Coordination Agency). 